\title{
Allelopathic influence of common buckwheat root residues on selected weed species
}

\author{
Magdalena Szwed ${ }^{1} \cdot$ Wiesław Wiczkowski $^{2} \cdot$ Dorota Szawara-Nowak $^{2} \cdot$ Ralph L. Obendorf $^{3} \cdot$ Marcin Horbowicz $^{1}(\mathbb{C}$
}

Received: 27 August 2018 / Revised: 27 December 2018 / Accepted: 7 May 2019 / Published online: 11 May 2019

(c) The Author(s) 2019

\begin{abstract}
This study was conducted to determine if common buckwheat (Fagopyrum esculentum Moench) root residues (BRR) in soil are effective in limiting the growth and metabolic responses of barnyard grass (Echinochloa crus-galli (L.) P. Beauv.), wind grass (Apera spica-venti L.), cleavers (Galium aparine L.), and tiny vetch (Vicia hirsuta L.). After removal of above ground parts, BRR of 14-day-old buckwheat plants remained in soil for an additional 7 days when the weeds were seeded. After 30 days of growth, biomass of above ground parts of the weeds as well as free and bound phenolic acids and flavonoids were determined. Antioxidant capacity and peroxidase activity were measured in barnyard grass and cleavers. The biomass of 30-day-old plants of barnyard grass and cleavers grown in bare soil was approximately 5- and 3.5-fold higher, respectively, than in plants grown in the presence of BRR. BRR did not affect the biomass of wind grass and tiny vetch plants, but activate the antioxidant response, increase in peroxidase activity, and the content of phenolic compounds in weed tissues, which indicates an adaptation to the stressful environmental conditions.
\end{abstract}

Keywords Fagopyrum esculentum $\cdot$ Allelopathy $\cdot$ Growth $\cdot$ Phenolic acids $\cdot$ Flavonoids

\section{Introduction}

The influence of common buckwheat (Fagopyrum esculentum Moench) on other plants has been known for hundreds of years (Tominaga and Uezu 1995; Kalinova et al. 2005; Golisz et al. 2007b, reviewed by Falquet et al. 2015). Buckwheat tissues contain numerous compounds with potential allelopathic properties (Iqbal et al. 2002; Kalinova et al. 2007; Golisz et al. 2007a). It is generally believed that

Communicated by A. Gniazdowska-Piekarska.

Electronic supplementary material The online version of this article (https://doi.org/10.1007/s11738-019-2885-y) contains supplementary material, which is available to authorized users.

Marcin Horbowicz

mhorbowicz@uph.edu.pl

1 Department of Biology, Siedlce University of Natural Sciences and Humanities, Prusa 14, 08-110 Siedlce, Poland

2 Institute of Animal Reproduction and Food Research of Polish Academy of Sciences, Tuwima 10, 10-748 Olsztyn, Poland

3 College of Agriculture and Life Sciences, Cornell University, 709 Bradfield Hall, Ithaca, NY 14853-1901, USA various phenolic acids and flavonoids are responsible for the weed suppressive activity of buckwheat (Kalinova et al. 2005; Golisz et al. 2007b; Kalinova and Vrchotova 2009). In addition, it has been reported that the suppression of some weeds is caused by the light competition of rapidly growing buckwheat plants (Bicksler and Masiunas 2009; Björkman and Shail 2013).

Studies on the allelopathic properties of plants are often carried out using aqueous, alcoholic, or other extracts for germination and/or the growth of seedlings of crop plants as well as weeds (Golisz et al. 2007b). Buckwheat extracts enhanced the content of phenolic compounds and flavonoids in tomato and maize tissues, which may be related to activation of the defense mechanism to stressful conditions (Szwed et al. 2014). There are other compounds in buckwheat that may have allelopathic efficiency (Kalinova et al. 2007, 2011; Szwed et al. 2014). It is known that the presence of buckwheat residues in soil can suppress various weeds (Tsuzuki and Dong 2003; Xuan and Tsuzuki 2004; Kato-Noguchi et al. 2007; Kumar et al. 2008, 2009).

Data available in the literature indicate that the accumulation of reactive oxygen species (ROS) in plant cells is under the influence of many allelopathic compounds present in the environment (Pergo and Ishii-Iwamoto 2011; Kaur 
et al. 2012; Chi et al. 2013). Research conducted by Kaur et al. (2012) showed that essential oils produced by redstem wormwood (Artemisia scoparia Waldst. \& Kitam.) resulted in the generation of ROS in the roots of 5-day wheat seedlings, increased lipid peroxidation, loss of membrane permeability, and death of root cells. Activation of antioxidant mechanisms was found to be under the influence of phenolic compounds and flavonoids (Pergo and Ishii-Iwamoto 2011; Mahmood et al. 2013; Ahuja et al. 2015).

The various compounds present in buckwheat plants are responsible for the allelopathic properties: flavonoids, phenolic acids, fatty acids, and alkaloids. Golisz et al. (2007b) found a high content of flavonoids and phenolic acids in Polish buckwheat cultivars, and they believe that rutin is the main allelopathic compound of these cultivars. Above ground tissues of buckwheat also contain gallic acid which caused a stronger inhibiting effect on the growth of dicotyledonous species than of grass species (Iqbal et al. 2003; Kato-Noguchi et al. 2007). In addition to flavonoids and phenolic acids, 4-hydroxyacetophenone was also identified in buckwheat root exudates and in extracts of soil after buckwheat cultivation (Kalinova et al. 2007). Tsuzuki and Dong (2003) identified ferulic, caffeic, and chlorogenic acids, as well as fatty acids among the allelochemicals in buckwheat. In other studies, eugenol, coniferyl alcohol, and 3,4,5-trimethoxyphenol were identified in buckwheat stems, leaves, and roots (Kalinova et al. 2011). In the above ground parts of buckwheat, Iqbal et al. (2002) found the alkaloids fagomine, 4-piperidone, and 2-piperidinomethanol which showed a strong inhibitory effect on lettuce growth. Despite many studies, there is no conclusive evidence of which compounds are directly responsible for the phenomenon of allelopathy in buckwheat. Probably, the whole set of compounds present in buckwheat tissues is involved in this phenomenon, along with microorganisms present in the soil (Gfeller et al. 2018). Moreover, Kumar et al. (2008) suggested that the mechanisms by which buckwheat residue can suppress weeds may include biological control of fungal pathogens and decreased nitrogen availability.

Some barnyard grass biotypes have evolved cross resistance to some herbicides, including imazamox, imazethapyr, and penoxsulam (Riar et al. 2013). Wind grass (loose silky bentgrass) (Apera spica-venti L.) is an important weed in Europe with an increasing number of herbicide-resistant populations (Babineau et al. 2017). Therefore, it is important to identify alternative methods to combat this weed. Tominaga and Uezu (1995) showed that the inhibition of plant growth by extracts from the soil in which buckwheat grew inhibited root elongation of barnyard grass and purslane (Portulaca oleracea L.), but had no effect on the growth of Galinsoga ciliata (Raf.) S.F. Blake.

Common buckwheat can alter its root exudation after weed recognition and suppresses its growth, as was found for Amaranthus retroflexus (Gfeller et al. 2018). Kumar et al. (2008) reported that buckwheat residues in soil suppress Powell amaranth (Amaranthus powellii S. Wats.), shepherd's-purse (Capsella bursa-pastoris L.), and corn chamomile (Anthemis arvensis L.).

In our preliminary screening tests, whole buckwheat plant residues as well as the root residues alone affected germination, growth, and biomass of several weed species. These preliminary tests revealed a much stronger allelopathic effect of the buckwheat roots alone without the aerial parts. Among the economically important weeds tested, two species, barnyard grass, and cleavers were particularly sensitive to buckwheat root residues in the soil, and two other weed species, wind grass and tiny vetch, were resistant. It has been hypothesized that the remains of buckwheat in the soil will have a lower impact on the content of antioxidants in the tissues of species that are not resistant to these residues than in resistant ones.

The aim of our study was to identify links between some metabolic indicators including the concentration of phenolic acids and flavonoids, peroxidase activity, and antioxidant potential and the differential tolerance of four weed species to buckwheat root residues that remain in the soil. These indicators are related to the scope of oxidative stress in plants.

\section{Materials and methods}

\section{Plant material and growth conditions}

We examined monocotyledonous and dicotyledonous weed species that occur in Europe and the USA and have strong competitive interactions. The monocotyledonous weeds studied were barnyard grass [Echinochloa crus-galli (L.) P. Beauv.; EPPO code ECHCG] and wind grass (A. spicaventi $\mathrm{L}$.; EPPO code APESV), and the dicotyledonous weeds were cleavers (bedstraw and catchweed) (Galium aparine L.; EPPO code GALAP) and tiny vetch (Vicia hirsuta L.; EPPO code VICHI). Weed seeds were collected from plants found in fields of cereals and root crops near Radzyń Podlaski (Eastern Poland). Breaking of seed dormancy in the case of barnyard grass and cleavers was performed by a 2-week wet stratification. The vetch seeds were scarified in concentrated sulphuric acid for $30 \mathrm{~min}$ and then rinsed five times with distilled water. After that, the seeds were sterilized for $2 \mathrm{~min}$ in $70 \%$ ethyl alcohol and then for $10 \mathrm{~min}$ in 5\% sodium hypochlorite with a drop of detergent. Subsequently, the seeds were rinsed once in $0.01 \mathrm{~N} \mathrm{HCl}$ and three times with distilled each time water, within $10 \mathrm{~min}$. Next, the seeds were stored at room temperature in the dark and dry conditions until used in this study. 
The study was conducted in air-conditioned plant growth room and focused on the impact of soil containing buckwheat root residues (BRR) on the growth of the weed species by measuring the mean weight of the plant (biomass). Common buckwheat (F. esculentum Moench, cv. Hruszowska) seeds were sown in four containers $(80 \times 15 \times 15 \mathrm{~cm}$; length $\times$ with $\times$ depth) filled with commercial horticultural soil $\left(6 \mathrm{~kg} ; 18 \mathrm{dm}^{3}\right.$, HIT-TORF, pH 6.48; $6.9 \mathrm{~g} \mathrm{~N} \mathrm{~kg}^{-1}$; $0.65 \mathrm{~g} \mathrm{P} \mathrm{kg}^{-1}$, Poland). Temperature in the air-conditioned plant growth room was maintained at $24 \pm 2{ }^{\circ} \mathrm{C}$ during days $\left(16 \mathrm{~h}\right.$ ) and $18 \pm 2{ }^{\circ} \mathrm{C}$ during nights $(8 \mathrm{~h}$ ). PAR (ca. $100 \mu \mathrm{mol} \mathrm{m} \mathrm{m}^{-2} \mathrm{~s}^{-1}$ ) was provided by high-pressure sodium lamps ( $400 \mathrm{~W}$, Plantaster, Osram, Germany). The containers with growing buckwheat were watered every morning. After 14 days of buckwheat plant growth, the aboveground parts of buckwheat plants were removed, but the roots remained in the soil for an additional 7 days when weed seeds were sown (100-120 per container). The initial root biomass in soil was $193 \pm 32 \mathrm{~g}$ in one container. To soil of another group of containers, whole buckwheat plants were added after they have been cut into small parts. The biomass of whole plants in one container was, on average, $521 \pm 44 \mathrm{~g}$. Each weed species was seeded in different sets of two containers for each treatment after 7-day decomposition of buckwheat in soil. The control soil containers without buckwheat plants and roots were incubated under identical conditions.

\section{Assay of biomass, antioxidant capacity, and peroxidase activity}

The mean biomass per plant of above ground parts of weeds was determined 30 days after sowing. Each combination (control, soil with remnants of buckwheat) contained two containers in which weed seeds were sown. The biomass of one plant was determined by dividing the weight of all plants by their number. The biomass measurements were made in four replications, with one replicate being the average mass of aboveground parts of one plant growing in one half of each container.

The antioxidant capacity and peroxidase activity also were determined in fresh tissues of barnyard grass and cleavers. The total antioxidant capacity was measured using the DPPH ${ }^{`}$ radical reduction method (1,1-diphenyl-2-picrylhydrazyl, Sigma), according to which its quenching is associated with a change in the color of the solution from dark violet to yellow (Brand-Williams et al. 1995).

Peroxidase activity was determined according to the method described by Velikova et al. (2000). This method is based on the oxidation of guaiacol by hydrogen peroxide, resulting in the formation of a red-brown color, whose concentration was measured spectrophotometrically.

The degree of plasma membrane damage, expressed as leakage of electrolytes, was determined by the method described by Uddin et al. (2014) using a conductivity meter (HACH conductivity/TDS meter 44600-00, Poland).

\section{Determination of free and bound phenolic acids and flavonoids}

Plant samples were freeze-dried (Christ Alpha 1-2 LD+, Germany), and pulverized tissues were analyzed by HPLC-MS/MS for the concentration of various forms of phenolic acids and flavonoids (free, esters, and glycosides). The profile and content of phenolic acids and flavonoids were determined according to the modified method of Wiczkowski et al. (2016). Briefly, a crude extract was obtained from 0.2 -g freeze-dried plant samples by extraction using thermomixer with mixture of methanol, water, and formic acid 80:19.9:0.1 (v/v). The extraction was repeated five times, and the obtained crude extracts were collected. Free forms of phenolic acids and flavonoids were isolated with diethyl after adjusting the initial extract to $\mathrm{pH} 2$ with $6 \mathrm{M}$ $\mathrm{HCl}$. Esters were hydrolyzed in nitrogen atmosphere for $4 \mathrm{~h}$ at room temperature with $4 \mathrm{M} \mathrm{NaOH}$. Subsequently, glycosides were hydrolyzed in the residues with $6 \mathrm{M} \mathrm{HCl}$ for $1 \mathrm{~h}$ at $100{ }^{\circ} \mathrm{C}$. After adjusting to $\mathrm{pH} 2$, free forms of phenolics released from glycosides and esters were extracted with diethyl ether. The all extractions were carried out in triplicates by use of sonication and centrifugation, and the obtained ether extracts were evaporated to dryness under stream of nitrogen at $35^{\circ} \mathrm{C}$. The phenolics, both free and released form bound forms, were dissolved in $80 \%$ methanol, and centrifuged and subjected to HPLC-MS/MS analysis. Aliquots of extracts were injected into an HPLC system equipped with an HALO C ${ }_{18}$ column $(2.7 \mu \mathrm{m}$ particles, $0.5 \times 50 \mathrm{~mm}$, Eksigent, USA) at $45{ }^{\circ} \mathrm{C}$ at a flow rate of $15 \mu \mathrm{L} \mathrm{min}{ }^{-1}$. The elution solvents were A (water/formic acid; 99.05/0.95; v/v) and B (acetonitrile/formic acid, 99.05/0.95, v/v). The gradient was used as follows: $5 \% \mathrm{~B}$ for $0.1 \mathrm{~min}, 5-90 \% \mathrm{~B}$ in $1.9 \mathrm{~min}, 90 \% \mathrm{~B}$ for $0.5 \mathrm{~min}, 90-5 \% \mathrm{~B}$ in $0.2 \mathrm{~min}$, and $5 \% \mathrm{~B}$ for $0.3 \mathrm{~min}$. For HPLC-MS/MS analysis, a QTRAP 5500 ion trap mass spectrometer (AB SCIEX, USA) was used. Optimal ESI-MS/MS conditions including nitrogen curtain gas, collision gas, ion spray source voltage, temperature, nebulizer gas, and turbo gas were as follows: $25 \mathrm{~L} \mathrm{~min}^{-1}$, $9 \mathrm{~L} \mathrm{~min}{ }^{-1},-4500 \mathrm{~V}, 350{ }^{\circ} \mathrm{C}, 35 \mathrm{~L} \mathrm{~min}^{-1}$, and $30 \mathrm{~L} \mathrm{~min}^{-1}$, respectively. Qualitative and quantitative analyses were conducted in the negative mode by multiple reaction monitoring (MRM) of selected ions in the first quadrupole (Q1) and third quadrupole (Q3). The transitions for ferulic acid, $p$-coumaric acid, chlorogenic acid, caffeic acid, sinapic acid, vanillic and iso-vanillic acid, protocatechuic acid, syringic acid, luteolin, apigenin, kaempferol, and quercetin were 193.1/134.1, 163.1/119.1, 353.2/191.1, 179.1/135.1, 223.1/164.1, 167.1/108.0, 153.0/109.0, 197.0/182.0, 285.1-133.1, 269.0-151.1, 285.0/93.0, and 301.1/179.1 
$(\mathrm{m} / \mathrm{z})$, respectively. Every compound was quantified based on the HPLC-MS/MS peak area at the appropriate MRM according to the corresponding linear calibration curves $\left(0.01-0.5 \mu \mathrm{g} \mathrm{mL}^{-1}\right)$.

\section{Statistical analyses}

Two-way analysis of variance (ANOVA) and Tukey's post hoc test were used to check the significance of differences in the biomass of aboveground parts of weed species, and chemical analyses of phenolic acids, flavonoids (free, and bound), antioxidant activity, and peroxidase activity. Treatment effects were regarded as statistically significant at $P<0.05$. The phenolic compounds, total antioxidant capacity, peroxidase activity, and leakage of electrolytes were analyzed in triplicate. Biomass measurements were made in four replications, with one replicate being the average mass of aboveground parts of one plant growing in one half of container. Calculations were performed using the Statistica 12 software package (StatSoft, Poland).

\section{Results}

Buckwheat root residues (BRR) present in the soil inhibited growth of barnyard grass and cleavers, no effect was observed in wind grass, and the mean weight (biomass) of tiny vetch plants increased by BRR in soil (Fig. 1). Inhibition of growth in two species was evident, because, in control treatments, the biomass of 30-day-old plants of barnyard grass and cleavers were approximately 5- and 3.5-fold higher, respectively, than in these plants grown in the presence of BRR. However, the addition of entire plants to the soil (roots and aboveground parts) did not significantly affect the biomass of the three weed species studied. In the case of wind grass, even growth stimulation was recorded, but this result is uncertain due to the poor germination of the seeds of this species.

In the examined weed species, the presence of transcinnamic acid ( $\mathrm{t}-\mathrm{CA})$ and its derivatives ( $p$-coumaric acid, synaptic, caffeic, ferulic, and chlorogenic) and benzoic acid derivatives (protocatechuic, syringic, vanillic, and iso-vanillic) have been demonstrated (Table 1; Supplemental Tables $\mathrm{S} 1, \mathrm{~S} 2, \mathrm{~S} 3$ ). The quantitatively dominate acid was t-CA, the concentration of which ranged from 2100 to $7700 \mu \mathrm{g} \mathrm{g}^{-1}$ of dry matter (Supplemental Table S1). This acid was present in free and bound forms as conjugated esters and glycosides. Relative to the control treatment, the presence of BRR resulted in a twofold increase in the total concentration and formed in cleavers and wind grass. In cleavers and in wind grass, respectively, a significant increase in the concentration of t-CA glycosides was found 8 and 28 times higher than those in control plants.

Among the trans-cinnamic acid derivatives, the highest concentration in the leaves of the evaluated species was caffeic acid, and the lowest concentration was sinapic acid (Supplemental Tables S2 and S3). The influence of BRR on accumulation of caffeic acid and sinapic acid was ambiguous and depended on the plant species and the acid being evaluated. However, the concentration of their glycosides increased in most species, but to a lesser extent than glycosides of trans-cinnamic acid (Supplemental Table S1). The BRR in the soil caused an increase in the total content of phenolic acids in the leaves of all weed species studied (Table 2). The content of free phenolic acids was increased by BRR in three of the four weed species, with the exception of tiny vetch. In the case of glycosides of phenolic acids, a particularly large effect of BRR occurred in the leaves of cleavers and wind grass. The presence of BRR increased glycoside content 17 -fold in cleavers and 27 -fold in wind grass. The impact of the BRR led to an increase in the content of benzoic acid derivatives in the leaves of barnyard grass and cleavers (Table 2; Supplemental Tables S2 and S3). In the
Fig. 1 Biomass (mean weight of plant aboveground parts \pm SD) of 30-day-old plants of four weed species grown in the soil with common buckwheat residues and without such residues (control). (1) Barnyard grass [E. crus-galli (L.) P. Beauv.]; (2) cleavers (G. aparine L.);

(3) wind grass (A. spica-venti L.); (4) tiny vetch (V. hirsuta

L.). Results with the same letter were not significantly different at $P<0.05$ (post hoc Tukey's test)

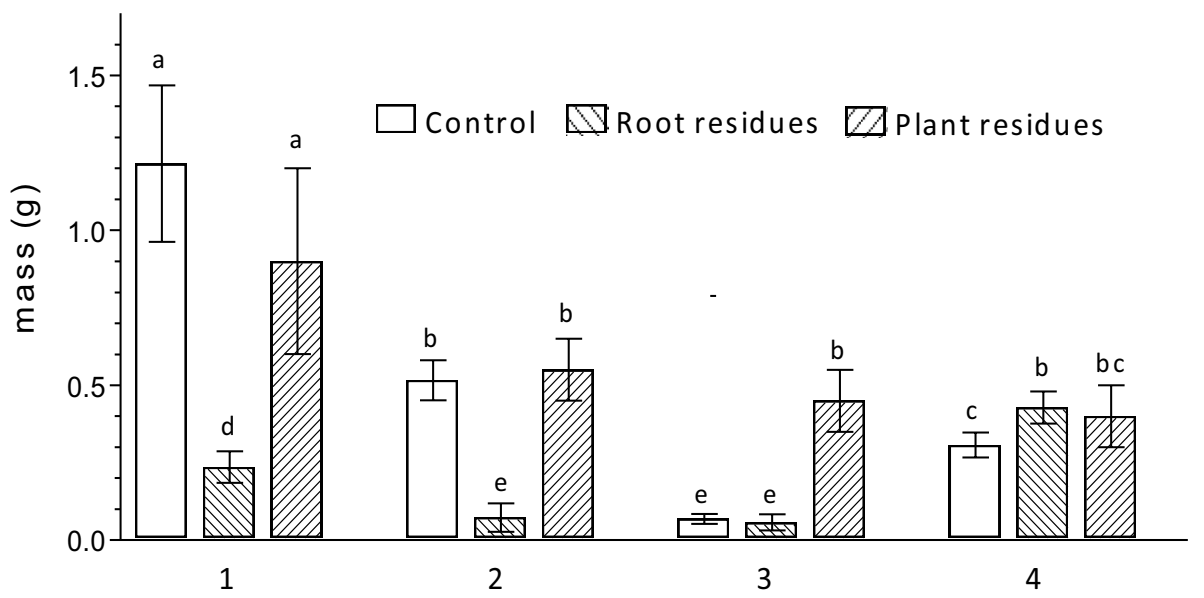


Table 1 Concentration of total free and bound phenolic acids in the leaves of four weed species grown in the control soil and soil-contained buckwheat root residues (BRR)

\begin{tabular}{|c|c|c|c|c|}
\hline Treatment & $\begin{array}{l}\text { Barnyard grass (E. crus- } \\
\text { galli (L.) P. Beauv.) }\end{array}$ & $\begin{array}{l}\text { Cleavers }(G . \\
\text { aparine } \mathrm{L} .)\end{array}$ & $\begin{array}{l}\text { Wind grass }(A . \\
\text { spica-venti } \mathrm{L} .)\end{array}$ & Tiny vetch ( $V$. hirsuta L.) \\
\hline \multicolumn{5}{|c|}{ Total free phenolic acids $(\mathrm{F})$} \\
\hline Control & $102.2 \pm 4.1^{\mathrm{b}, \dagger}$ & $1624 \pm 76^{\mathrm{b}}$ & $1375 \pm 80^{\mathrm{b}}$ & $32.70 \pm 0.20^{\mathrm{a}}$ \\
\hline BRR & $222.9 \pm 8.9^{\mathrm{a}}$ & $3129 \pm 91^{\mathrm{a}}$ & $2191 \pm 26^{\mathrm{a}}$ & $31.56 \pm 0.82^{\mathrm{a}}$ \\
\hline \multicolumn{5}{|c|}{ Total phenolic acid esters (E) } \\
\hline Control & $2165 \pm 20^{\mathrm{b}}$ & $2553 \pm 100^{\mathrm{a}}$ & $2172 \pm 82^{\mathrm{a}}$ & $109.7 \pm 3.5^{\mathrm{b}}$ \\
\hline BRR & $2596 \pm 128^{a}$ & $2614 \pm 63^{\mathrm{a}}$ & $1586 \pm 8.2^{\mathrm{b}}$ & $130.6 \pm 2.8^{\mathrm{a}}$ \\
\hline \multicolumn{5}{|c|}{ Total phenolic acid glycosides (G) } \\
\hline Control & $145.3 \pm 3.3^{\mathrm{a}}$ & $155.2 \pm 4.3^{\mathrm{b}}$ & $138.0 \pm 1.8^{\mathrm{b}}$ & $2454 \pm 34^{b}$ \\
\hline BRR & $103.0 \pm 4.0^{\mathrm{b}}$ & $2712 \pm 87^{a}$ & $3771 \pm 245^{\mathrm{a}}$ & $3471 \pm 9.1^{\mathrm{a}}$ \\
\hline \multicolumn{5}{|c|}{ Total phenolic acids $(F+E+G)$} \\
\hline Control & $2413 \pm 27^{\mathrm{b}}$ & $4332 \pm 172^{\mathrm{b}}$ & $3685 \pm 40^{\mathrm{b}}$ & $2596 \pm 38^{\mathrm{b}}$ \\
\hline BRR & $2922 \pm 133^{\mathrm{a}}$ & $8455 \pm 242^{\mathrm{a}}$ & $7549 \pm 211^{\mathrm{a}}$ & $3633 \pm 11^{\mathrm{a}}$ \\
\hline
\end{tabular}

$\dagger$ All data are presented as the mean \pm SD. Results with the same letter were not significantly different at $P<0.05$ (post hoc Tukey's test). Comparisons were made between control and buckwheat root residues treatments (BRR) within each combination of total free and bound phenolic acids and within each weed species

\begin{tabular}{|c|c|c|c|c|}
\hline Treatment & $\begin{array}{l}\text { Barnyard grass (E. crus- } \\
\text { galli (L.) P. Beauv.) }\end{array}$ & $\begin{array}{l}\text { Cleavers }(G . \\
\text { aparine } \mathrm{L} .)\end{array}$ & $\begin{array}{l}\text { Wind grass }(A . \\
\text { spica-venti } \mathrm{L} .)\end{array}$ & Tiny vetch ( $V$. hirsuta L.) \\
\hline \multicolumn{5}{|c|}{ Total trans-cinnamic acid } \\
\hline Control & $2130 \pm 35^{\mathrm{a}}$ & $3805 \pm 174^{\mathrm{b}}$ & $3549 \pm 5.8^{\mathrm{b}}$ & $2354 \pm 35^{\mathrm{b}}$ \\
\hline BRR & $2430 \pm 131^{\mathrm{a}}$ & $7737 \pm 237^{\mathrm{a}}$ & $7393 \pm 209^{a}$ & $2923 \pm 8.3^{\mathrm{a}}$ \\
\hline \multicolumn{5}{|c|}{ Total trans-cinnamic acid derivatives } \\
\hline Control & $92.4 \pm 2.1^{\mathrm{a}}$ & $215.1 \pm 3.9^{\mathrm{b}}$ & $70.4 \pm 0.7^{\mathrm{a}}$ & $81.1 \pm 1.5^{\mathrm{b}}$ \\
\hline BRR & $88.9 \pm 1.0^{\mathrm{a}}$ & $372.2 \pm 2.0^{\mathrm{a}}$ & $62.0 \pm 0.1^{\mathrm{b}}$ & $240.9 \pm 0.3^{\mathrm{a}}$ \\
\hline \multicolumn{5}{|c|}{ Total benzoic acid derivatives } \\
\hline Control & $190.6 \pm 5.7^{\mathrm{b}, \dagger}$ & $312.1 \pm 6.1^{\mathrm{b}}$ & $66.5 \pm 1.1^{\mathrm{b}}$ & $161.6 \pm 4.4^{\mathrm{b}}$ \\
\hline BRR & $403.6 \pm 3.8^{\mathrm{a}}$ & $346.0 \pm 2.2^{\mathrm{a}}$ & $94.8 \pm 2.2^{\mathrm{a}}$ & $469.2 \pm 3.3^{\mathrm{a}}$ \\
\hline \multicolumn{5}{|c|}{ Total flavonoids } \\
\hline Control & $7.0 \pm 0.1^{\mathrm{b}}$ & $6.6 \pm 0.1^{\mathrm{b}}$ & $7.9 \pm 0.1^{\mathrm{b}}$ & $389.3 \pm 11.0^{\mathrm{b}}$ \\
\hline BRR & $10.4 \pm 0.1^{\mathrm{a}}$ & $17.5 \pm 0.0^{\mathrm{a}}$ & $14.5 \pm 0.5^{\mathrm{a}}$ & $563.0 \pm 15.0^{\mathrm{a}}$ \\
\hline
\end{tabular}

${ }^{\dagger}$ All data are presented as the mean \pm SD. Results with the same letter were not significantly different at $P<0.05$ (post hoc Tukey's test). Comparisons were made between control and buckwheat root residues treatments (BRR) within total benzoic acid derivatives or within total trans-cinnamic acid derivatives and within each weed species
Table 2 Concentration of total trans-cinnamic acid, transcinnamic acid derivatives, benzoic acid derivatives, and flavonoids ( $\mu \mathrm{g} \mathrm{g}^{-1}$ dry weight) in the leaves of four weed species grown in the control soil and soil-contained buckwheat root residues (BRR) tissues of wind grass, a decrease in the concentration of t-CA derivatives was observed, and in barnyard grass, it reached a concentration close to the control.

In the leaves of the evaluated weed species, the presence of free and bound forms of quercetin, kaempferol, apigenin, and luteolin has been demonstrated (Supplemental Table S4). The concentration of flavonoids was low, compared to the content of phenolic acids, and did not exceed $5 \mu \mathrm{g} \mathrm{g}^{-1}$ of dry matter. The exception was tiny vetch leaves in which the tissue concentration of apigenin exceeded $380 \mu \mathrm{g} \mathrm{g}^{-1}$. Under the influence of BRR in the soil, an increase in the concentration of flavonoid glycosides occurred in tissues of all species (Supplemental
Table S4). While the quercetin concentration increased in tissues of barnyard grass and cleavers, the quercetin concentration decreased in leaves of tiny vetch and remained unchanged in leaves of wind grass.

Inhibition of the biomass accumulation of weed species in the presence of BRR in the soil was associated with an increase in the concentration of trans-cinnamic acid and total phenolic acids in leaves as confirmed by Pearson's correlation coefficients $(r)$. Statistical analysis of the data showed a negative significant correlation between the biomass of seedlings of the all examined weed species and content of trans-cinnamic acid $(r=-0.555 ; P=0.05)$, 


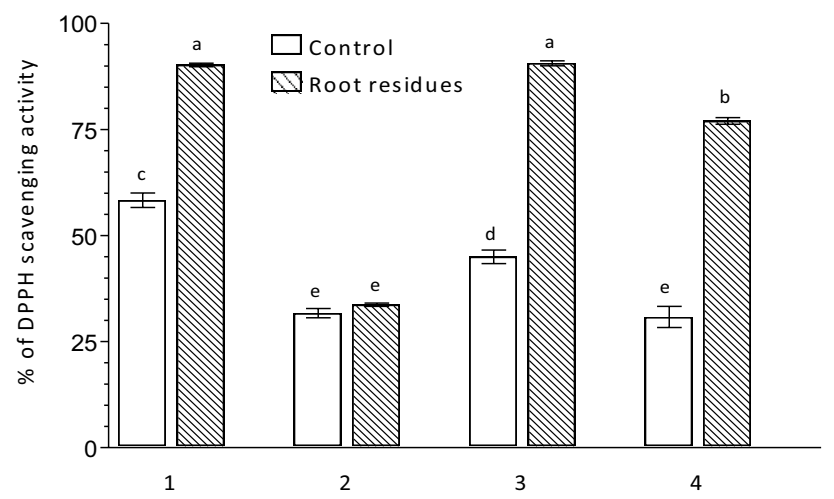

Fig. 2 Antoxidant activity in tissues of 30-day-old plants of weed species grown in the soil with common buckwheat root residues and without such residues (control). (1) and (2) Barnyard grass [E. crusgalli (L.) P. Beauv.] leaves and epicotyls, respectively; and cleavers (G. aparine L.) leaves (3) and hypocotyls (4), respectively. Results with the same letter were not significantly different at $P<0.05$ (post hoc Tukey's test)

as well as between the biomass and total phenolic acids $(r=-0.546 ; P=0.05)$.

To confirm the occurrence of oxidative stress, measurements of antioxidant potential through the rate of reduction of radical DPPH in tissues of BRR-sensitive species were conducted (Fig. 2). In the leaves and hypocotyls of cleavers under the influence of BRR, a more than twofold increase in the antioxidant potential was found. In the case of the barnyard grass leaves, this increase was over $34 \%$, while, in the epicotyl of this species, the BRR did not affect the antioxidant potential.

During the assessment of BRR on the level of peroxidase activity, different reactions were observed in the tissues of both weed species (Fig. 3). The presence of BRR caused an increase in peroxidase activity in barnyard grass leaves and epicotyls. In the tissues of cleavers, this response was different, because BRR did not affect peroxidase activity in the leaves, whereas a decrease in peroxidase activity occurred in the hypocotyl tissues.

\section{Discussion}

Plant allelopathy is the process whereby organic compounds released from one species affect the growth and development of other plants. Mechanisms by which allelochemicals can suppress weeds directly may be accompanied by indirect effects due to control of fungal pathogens and decreased nitrogen availability (Kumar et al. 2009). Weed suppression can be achieved by changes in weed emergence, biomass, seed set, and seed bank (Liebman and Davis 2000).

The results of our research show the reduction of biomass of two weed species, barnyard grass and cleavers, under the

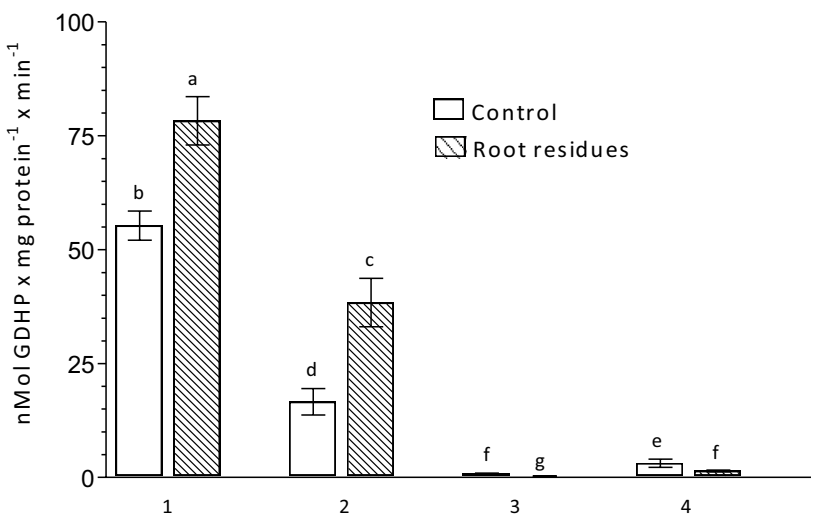

Fig. 3 Antoxidant activity in tissues of 30-day-old plants of weed species grown in the soil with common buckwheat root residues and without such residues (control). (1) and (2) Barnyard grass (E. crusgalli (L.) P. Beauv.) leaves and epicotyls, respectively; and cleavers (G. aparine L.) leaves (3) and hypocotyls (4), respectively. Results with the same letter were not significantly different at $P<0.05$ (post hoc Tukey's test)

influence of buckwheat root residues (BRR), and the lack of that effect when residues of entire plants of buckwheat occurred in soil (Fig. 1). Such a phenomenon is reported for the first time, and its causes are unknown. Tominaga and Uezu (1995) previously noticed that the presence of buckwheat seedlings clearly inhibited the growth of barnyard grass growing next to it. In addition, Kumar et al. (2008) have shown that residues of whole buckwheat plants in the soil suppressed the growth of Powell amaranth (A. powellii S. Wats.), shepherd's-purse (C. bursa-pastoris L.), and corn chamomile (A. arvensis L.), and reported that the biomass of all three weeds was reduced in buckwheat residue compared to bare soil.

It is widely believed that allelochemicals influence the level of non-enzymatic antioxidants and increase the activity of enzymes (Ding et al. 2007; Pergo and Ishii-Iwamoto 2011; García-Sánchez et al. 2012; Ahuja et al. 2015). The major group of non-enzymatic antioxidants are polyphenolic compounds whose role is the removal of reactive oxygen species which affects many metabolic processes in cells (Cruz-Ortega et al. 2007). The results of our study demonstrated that the presence of BRR in the soil resulted in a significantly increased concentration of glycosides of phenolic acids and flavonoids in the leaves of the weeds (Tables 1, 2; Supplemental Tables 1-5). Among the phenolic acids, this phenomenon increased mainly the trans-cinnamic acid and benzoic acid derivatives and, to a lesser extent, the cinnamic acid derivatives. It is not clear what functions the glycoside forms of phenolics induce under the influence of these stress factors. According to Politycka (1996), the level of phenolic glycosides correlated inversely with membrane stability, which may indicate that a high content of phenolics may 
promote the leakage of electrolytes. However, our studies did not confirm the occurrence of this phenomenon.

In general, BRR increases the level of phenolic acids and flavonoids to a greater extent in barnyard grass and cleavers and to a lesser extent in wind grass and tiny vetch (Tables 1 , 2; Supplemental Tables 1-5). Increasing the concentration of phenolic acids and flavonoids in the leaves of weeds not sensitive to BRR indicates that these plants also may be subjected to oxidative stress caused by this factor. However, it does not inhibit their growth, probably because the defense mechanisms in wind grass and tiny vetch seem to be more effective than in barnyard grass and cleavers. Calculated negative correlation between the content of trans-cinnamic acid and plant biomass, as well as between the total phenolic acids and plant biomass suggests that the concentration of some polyphenols can be an indicator of the allelopathic influence of BRR on weed species. The increase in the content of phenolic compounds occurred both in the species of weeds sensitive to the remains of buckwheat roots as well as not being affected by it. This means that the allelopathic stress arises in the tissues of all species tested. However, various anti-stress defense mechanisms cause that growth is inhibited in some of them, while, in others, there was no such influence.

An important part of the allelopathic mechanism is the induction of oxidative stress and the disruption of the redox status in the tissues of acceptor plants (Cruz-Ortega et al. 2007). The results obtained in our study showed that the presence of BRR in the soil increased the total antioxidant capacity in the leaves of barnyard grass as well as leaves and hypocotyls of cleavers (Fig. 2). No difference was found compared to the control plants only in barnyard grass epicotyl tissues after 30 days of growth in the presence of BRR. According to Dudonné et al. (2009), the antioxidant activity of plant extracts correlated with the concentration of phenolic compounds. Our results confirmed that the increase in total antioxidant capacity was associated with an increased accumulation of polyphenolic compounds in tissues of the weeds growing in soil with BRR.

An important component of the enzymatic defense against reactive oxygen species (ROS) is peroxidases, which catalyze the decomposition reaction of hydrogen peroxide (Gechev et al. 2006). Increased peroxidase activity in plants growing in soil with BRR probably is related to the enhanced level of the ROS (Fig. 3). Higher peroxidase activity in barnyard grass growing in the soil containing BRR was confirmed in our study. However, this relationship was not observed in cleavers. A different reaction of both species to allelochemical stress may be associated with the activation of various defense mechanisms against oxidative stress. It is feasible; such distinct response is consequence of both, complex composition of BRR released into the soil and indirect role of microorganism taking part in allelochemicals decay in the soil. The main reason for these differences may also be related to the unknown role of soil microorganisms (Kaur et al. 2009). The previous studies also pointed to the association of peroxidase activity with the presence of allelopathic compounds in the soil (Amist et al. 2014). Increased peroxidase activity resulting from solutions of pure phenolic compounds such $p$-hydroxybenzoic acid or coumarin has been reported (Ahrabi et al. 2011). Improving the efficiency of the mechanisms of neutralization of ROS by peroxidase may additionally be associated with an increase in the concentration of phenolic compounds which enhances the antioxidant capacity of plants (Grace and Logan 2000). According to Yamasaki et al. (1997), flavonoids can be an electron donor in these reactions.

\section{Conclusions}

The results presented here show inhibition of biomass accumulation of two weed species, barnyard grass, and cleavers, by the presence of buckwheat root residues in the soil. The observed inhibition of biomass accumulation was associated with some disturbances of secondary metabolism in tissues of weed species. Under conditions of allelochemical stress, activation of the antioxidant response, increase in peroxidase activity, and increase in the content of phenolic compounds in weed tissues were observed, which indicates an adaptation to the stressful environmental conditions. As stated here, the results reveal an allelopathic role of common buckwheat roots, and provide the basis for further studies enabling the use of common buckwheat residues for weed management.

Author contribution statement MS carried out plant experiments and basic analyses; WW and DS-N carried oud LC-MS analyses of phenolic compounds; RLO and MH contributed to data analysis and preparing of manuscript. All authors read and approved the final manuscript.

Acknowledgements This work was supported in part by Ministry of Science and Higher Education (Poland) as a part of the statutory activities of the Faculty of Natural Sciences at the Siedlce University of Natural Sciences and Humanities (No. 13/91/S).

Open Access This article is distributed under the terms of the Creative Commons Attribution 4.0 International License (http://creativecommons.org/licenses/by/4.0/), which permits unrestricted use, distribution, and reproduction in any medium, provided you give appropriate credit to the original author(s) and the source, provide a link to the Creative Commons license, and indicate if changes were made. 


\section{References}

Ahrabi F, Enteshari S, Moradshahi A (2011) Allelopathic potential of para-hydroxybenzoic acid and coumarin on canola: Talaieh cultivar. J Med Plants Res 5:5104-5109

Ahuja N, Singh HP, Batish DR, Kohli RK (2015) Eugenol-inhibited root growth in Avena fatua involves ROS-mediated oxidative damage. Pestic Biochem Physiol 118:64-70. https://doi.org/10.1016/j. pestbp.2014.11.012

Amist N, Singh NB, Yadav K (2014) Interactive effects of rice residue and water stress on growth and metabolism of wheat seedlings. J Stress Physiol Biochem 10:232-245

Babineau M, Mathiassen SK, Kristensen M, Kudsk P (2017) Fitness of ALS-inhibitors herbicide resistant population of loose silky bentgrass (Apera spica-venti). Front Plant Sci 8:1660. https://doi. org/10.3389/fpls.2017.01660

Bicksler AJ, Masiunas JB (2009) Canada thistle (Cirsium arvense) suppression with buckwheat or sudangrass cover crops and mowing. Weed Technol 23:556-563. https://doi.org/10.1614/WT-09-050.1

Björkman T, Shail JW (2013) Using a buckwheat cover crop for maximum weed suppression after early vegetables. HortTechnology 23:575-580

Brand-Williams W, Cuvelier ME, Berset C (1995) Use of free radical method to evaluate antioxidant activity. Lebensm Wiss Technol 28:25-30. https://doi.org/10.1016/S0023-6438(95)80008-5

Chi W-Ch, Chen Y-A, Hsiung Y-Ch, Fu S-F, Chou Ch-H, Trinh NN, Chen Y-Ch, Huang H-J (2013) Autotoxicity mechanism of Oryza sativa: transcriptome response in rice roots exposed to ferulic acid. BMC Genomics 14:351. https://doi. org/10.1186/1471-2164-14-351

Cruz-Ortega R, Lara-Núñez A, Anaya AL (2007) Allelochemical stress can trigger oxidative damage in receptor plants. Plant Signal Behav 2:269-270. https://doi.org/10.1111/j.1365-3040.2006.01575

Ding J, Sun Y, Xiao CL, Shi K, Zhou YH, Yu JQ (2007) Physiological basis of different allelopathic reactions of cucumber and fig-leaf gourd plants to cinnamic acid. J Exp Bot 58:3765-3773. https:// doi.org/10.1093/jxb/erm227

Dudonné S, Vitrac X, Coutiére P, Woillez M, Mérillon J-M (2009) Comparative study of antioxidant properties and total phenolic content of 30 plant extracts of industrial interest using DPPH, ABTS, FRAP, SOD and ORAC assays. J Agric Food Chem 57:1768-1774. https://doi.org/10.1021/jf803011r

Falquet B, Gfeller A, Pourcelot M, Tschuy F, Wirth J (2015) Weed suppression by common buckwheat: a review. Environ Control Biol 53:1-6. https://doi.org/10.2525/ecb.53.1

García-Sánchez M, Garrido I, Casimiro IJ, Casero PJ, Espinosa F, García-Romera I, Aranda E (2012) Defense response of tomato seedlings to oxidative stress induced by phenolic compounds from dry olive mill residue. Chemosphere 89:708-716. https:// doi.org/10.1016/j.chemosphere.2012.06.026

Gechev TS, Van Breusegem F, Stone JM, Denev I, Laloi C (2006) Reactive oxygen species as signals that modulate plant stress responses and programmed cell death. BioEssays 28:1091-1101. https://doi.org/10.1002/bies.20493

Gfeller A, Glauser G, Etter C, Signarbieux C C, Wirth J (2018) Fagopyrum esculentum alters its root exudation after Amaranthus retroflexus recognition and suppresses weed growth. Front Plant Sci 9:50. https://doi.org/10.3389/fpls.2018.00050

Golisz A, Gawronska H, Gawronski SW (2007a) Influence of buckwheat allelochemicals on crops and weeds. Allelopathy $\mathbf{J}$ 19:337-349

Golisz A, Lata B, Gawronski SW, Fujii Y (2007b) Specific and total activities of the allelochemicals identified in buckwheat. Weed Biol Manag 7:164-171. https://doi.org/10.111 $1 /$ j.1445-6664.2007.00252.x
Grace SC, Logan BA (2000) Energy dissipation and radical scavenging by the plant phenylpropanoid pathway. Philos Trans R Soc Lond 355:1499-1510. https://doi.org/10.1098/rstb.2000.0710

Iqbal Z, Hiradate S, Noda A, Isojima SI, Fujii Y (2002) Allelopathy of buckwheat: assessment of allelopathic potential of extract of aerial parts of buckwheat and identification of fagomine and other related alkaloids as allelochemicals. Weed Biol Manag 2:110 115. https://doi.org/10.1046/j.1445-6664.2002.00055.x

Iqbal Z, Hiradate S, Noda A, Isojima SI, Fujii Y (2003) Allelopathic activity of buckwheat: isolation and characterization of phenolics. Weed Sci 51:657-662. https://doi.org/10.1614/00431 745(2003)051\%5b0657:AAOBIA\%5d2.0.CO;2

Kalinova J, Vrchotova N (2009) Level of catechin, myricetin, quercetin and isoquercitrin in buckwheat (Fagopyrum esculentum Moench), changes of their levels during vegetation and their effect on the growth of selected weeds. J Agric Food Chem 57:2719-2725. https://doi.org/10.1021/jf803633f

Kalinova J, Triska J, Vrchotova N (2005) Biological activity of phenolic compounds present in buckwheat plants. Allelopathy $\mathbf{J}$ $16: 123-129$

Kalinova J, Vrchotova N, Triska J (2007) Exudation of allelopathic substances in buckwheat (Fagopyrum esculentum Moench). J Agric Food Chem 55:6453-6459. https://doi.org/10.1021/Jf070 $795 \mathrm{u}$

Kalinova J, Triska J, Vrchotova N (2011) Occurence of eugenol, coniferyl alcohol and 3,4,5-trimethoxyphenol in common buckwheat (Fagopyrum esculentum Moench) and their biological activity. Acta Physiol Plant 33:1679-1685. https://doi. org/10.1007/s11738-010-0704-6

Kato-Noguchi H, Sugimoto H, Yamada M (2007) Buckwheat seedlings may inhibit other plant growth by allelopathic substances. Environ Control Biol 45:27-32. https://doi.org/10.2525/ ecb. 45.27

Kaur H, Kaur R, Kaur S, Baldwin IT, Inderjit (2009) Taking ecological function seriously: soil microbial communities can obviate allelopathic effects of released metabolites. PLoS One 4(3):e4700. https://doi.org/10.1371/journal.pone.0004700

Kaur S, Singh HP, Batish DR, Kohli RK (2012) Artemisia scoparia essential oil inhibited root growth involves reactive oxygen species (ROS)-mediated disruption of oxidative metabolism: in vivo ROS detection and alterations in antioxidant enzymes. Biochem Syst Ecol 44:390-399. https://doi.org/10.1016/j.bse.2012.06.015

Kumar V, Brainard DC, Bellinder RR (2008) Suppression of Powell amaranth (Amaranthus powellii), shepherd's-purse (Capsella bursa-pastoris), and corn chamomile (Anthemis arvensis) by buckwheat residues: role of nitrogen and fungal pathogens. Weed Sci 56:271-280. https://doi.org/10.1614/WS-07-106.1

Kumar V, Brainard DC, Bellinder RR (2009) Suppression of Powell amaranth (Amaranthus powellii) by buckwheat residues: role of allelopathy. Weed Sci 57:66-73. https://doi.org/10.1614/WS-D11-00006.1

Liebman M, Davis AS (2000) Integration of soil, crop and weed management in low-external-input farming systems. Weed Res 40:2747. https://doi.org/10.1046/j.1365-3180.2000.00164.x

Mahmood K, Khan MB, Song YY, Ye M, Baerson SR, Zeng RS (2013) Differential morphological, cytological and biochemical responses of two rice cultivars to coumarin. Allelopathy J 31:281-296

Pergo ÉM, Ishii-Iwamoto EL (2011) Changes in energy metabolism and antioxidant defense systems during seed germination of the weed species Ipomoea triloba L. and the responses to allelochemicals. J Chem Ecol 37:500-513. https://doi.org/10.1007/s1088 6-011-9945-0

Politycka B (1996) Peroxidase activity and lipid peroxidation in roots of cucumber seedlings influenced by derivatives of cinnamic and benzoic acids. Acta Physiol Plant 18:365-370. https://doi. org/10.1007/s11738-998-0027-z 
Riar DS, Norsworthy JK, Srivastava V, Nandula V, Bond JA, Scott RC (2013) Physiological and molecular basis of acetolactate synthase-inhibiting herbicide resistance in barnyard grass (Echinochloa crus-galli). J Agric Food Chem 61:278-289. https://doi. org/10.1021/jf304675j

Szwed M, Sławianowska J, Koczkodaj D, Mitrus J, Sytykiewicz H, Horbowicz M (2014) Allelopathic properties of extracts and some metabolites present in the tissues of common buckwheat (Fagopyrum esculentum Moench) seedlings. Acta Sci Pol Agric 13:139-151

Tominaga T, Uezu T (1995) Weed suppression by buckwheat. Current advances in buckwheat research. Shinsyu University Press, Japan, pp 693-697

Tsuzuki E, Dong YJ (2003) Buckwheat allelopathy: use in weed management. Allelopathy J 12:1-11

Uddin MN, Robinson RW, Caridi D (2014) Phytotoxicity induced by Phragmites australis: an assessment of phenotypic and physiological parameters involved in germination process and growth of receptor plant. J Plant Interact 9:338-353. https://doi. org/10.1080/17429145.2013.835879
Velikova V, Yordanov I, Edreva A (2000) Oxidative stress and some antioxidant systems in acid rain-treated bean plants. Protective role of exogenous polyamines. Plant Sci 151:59-66. https://doi. org/10.1016/S0168-9452(99)00197-1

Wiczkowski W, Szawara-Nowak D, Sawicki T, Mitrus J, Kasprzykowski Z, Horbowicz M (2016) Profile of phenolic acids and antioxidant capacity in organs of common buckwheat sprout. Acta Aliment Hung 45:250-257. https://doi.org/10.1556/066.2016.45.2.12

Xuan TD, Tsuzuki E (2004) Allelopathic plants: buckwheat (Fagopyrum spp.). Allelopathy J 13:137-148

Yamasaki H, Sakihama Y, Ikehara N (1997) Flavonoid-peroxidase reaction as a detoxification mechanism of plant cells against $\mathrm{H}_{2} \mathrm{O}_{2}$. Plant Physiol 115:1405-1412. https://doi.org/10.1104/ pp.115.4.1405

Publisher's Note Springer Nature remains neutral with regard to jurisdictional claims in published maps and institutional affiliations. 